\title{
Geospatial Analysis of Soil Properties and Their Effects on Maize and Cassava Production in Ohaji/Egbema Imo State, Nigeria
}

\author{
Fidelis Chinazor Okorie $^{1^{*}}$, Chikere-Njoku Chinyere ${ }^{2}$, J. Oduaro Ifeanyi ${ }^{1}$, Chikwendu Lazarus ${ }^{1}$ \\ ${ }^{1}$ Department of Geography and Environmental Management, Imo State University, Owerri, Nigeria \\ ${ }^{2}$ Department of Soil Science and Environment, Imo State University, Owerri, Nigeria \\ Email: ^fidelisokorie@yahoo.co.uk
}

How to cite this paper: Okorie, F.C., Chinyere, C.-N, Ifeanyi, J.O. and Lazarus, C. (2020) Paper Title. Open Access Library Journal, 7: e6259.

https://doi.org/10.4236/oalib.1106259

Received: March 23, 2020

Accepted: April 21, 2020

Published: April 24, 2020

Copyright $\odot 2020$ by author(s) and Open Access Library Inc.

This work is licensed under the Creative Commons Attribution International License (CC BY 4.0).

http://creativecommons.org/licenses/by/4.0/

\section{(c) (i) Open Access}

\begin{abstract}
This study geospatially analyzed the effects of soil physical and chemical properties on production of maize and cassava in Ohaji/Egbema of Imo State Nigeria. The research adopted a free survey method of sampling soils from ten (10) different locations (communities) in the area. Auger and soil profile samplings were performed and soil samples were bulked for laboratory analysis. Sampling sites were geo-referenced using handheld global positioning system (GPS) receiver for map production and digital elevation model (DEM) of the study area. Cassava and maize yield data from 1988-2017 were collected from the agricultural development programme (ADP) headquarters at Owerri, Imo State. Data were analyzed using different techniques including laboratory studies and analysis of variance (ANOVA). Variations in properties among soil horizons were obtained using coefficient of variation, and soil properties were correlated with crops. Results indicated that some soil properties showed high variations, such that at the two sampling depths $(0-20 \mathrm{~cm}$ and $20-40 \mathrm{~cm}$ ), soils were strongly acidic with low values in organic matter, total nitrogen, exchangeable bases and available phosphorous. Few soil properties correlated positively with, cassava at 0.05 (Total nitrogen $=0.5333$; Silt $=$ 0.7750 ) and maize at 0.01 (Total sand $=0.7774$; Coarse sand $=0.8742$ ) probability levels but generally, most soil properties significantly correlated negatively with the crops in the area. Thus, the soils contained low/less plant nutrient elements for crop production enhancement. It's paramount therefore, to improve the quality of soils and soil fertility in order to achieve sustainability of food security in the area.
\end{abstract}

\section{Subject Areas}

Agricultural Science 


\section{Keywords}

Geospatial Analysis, Effects, Soil Properties, Crop Production, Ohaji/Egbema, Nigeria

\section{Introduction}

It is envisaged that Africa's soil resource will continue to deteriorate, probably as a result of changes in climate, land use and human activities in general [1]. The main problems for soils in the African continent are contamination and irreversible losses due to increasing erosion. Soil erosion, in particular, is regarded as one of the major and most widespread forms of land degradation, and as such, poses severe limitations to sustainable agricultural land use [1].

However despite Nigerian government campaigns and slogans, farm production has not kept pace with food demand. Most food crops produced in the country come from the efforts of small-scale farmers who depend largely on traditional farming systems for their agricultural inputs [2]. The recurrent food crisis in Nigeria is partly due to high rate of population growth over the food production level and erratic amounts of food crops produced from year to year. This however, can be attributed to high susceptibility of the country to serious environmental hazards from low rainfall, extreme temperature, acid rain, gas flaring, oil spillage, poor soil quality, deforestation, continuous cropping and unhindered desert encroachment [3]. Arable crops such as cassava, maize, yam and cocoyam are the chief sources of dietary energy for the majority of the people living in the lowland tropics, and many of the sub-humid tropics of West and Central Africa [4].

Therefore, their production and utilization must be given prime attention in food policy. Even though farmers have not yet attained the desired technical efficiency in their production as a result of weak access to external inputs such as fertilizers and herbicides [5].

[6] pointed out that optimum soil nutrients are sine qua non for sustainable agriculture for food and nutrition security. [7], in their study concluded that rapid decline in crop yield was associated with continuous cropping in Netherlands. Also [8] noted that the low-available water holding capacity of the soil results in poor crop growth in the tropics. In another study, [9] believes that rising temperature affects soil moisture, which in turn could affect soil fertility. Supporting the above remark, [10] observed that the major agro-climatic constraints on agricultural production are related to insufficient, excessive or irregular moisture supply, which in turn will affect the length of growing period (LGP) of crops [11]. While assessing the characteristics of soils in the Guinea Savanna zone of Nigeria it is reported that bulk density increased down the profile, in accordance with increase in clay content.

According to [12], soil physical properties play a key role in soil sustainability 
and crop production; that they determine how easily plant roots can grow to access soil nutrients, and how easily water can flow through the soil to deliver these nutrients.

[13] reported that organic matter was generally highest in the top most horizon of Imo River Basin while it was consequently highest in the topsoil because of the continuous addition of organic matter to the soil surface by plant residues. [14], attributed this decreasing trend of organic matter with depth primarily to the effect of nutrient bio-cycling.

According to [15] ECEC is used to estimate the potential fertility of the soil, the possible response to fertilizer application and as a rough guide to the types of clay minerals present. Generally ECEC was reported to be low in Imo river basin [16] [17] [18]. Percentage Base Saturation (\% Bsat) is another good indicator of soil fertility [15]. According to [14], the low nitrogen in most of the pedons is a common phenomenon in the soils of Southeastern Nigeria and is as a result of the high nitrogen losses sustained in these soils through leaching of nitrates, as well as the rapid mineralization of organic matter under the isohyperthermic soil temperature regime.

Ultimately, physical factors such as climate, topography, land cover and specific soil characteristics have important effects on the processes of soil erosion and soil formation, which in turn affect crop production. Therefore, this study was investigating physic-chemical soil properties known as environmental factors among others, directly and indirectly influencing production of maize and cassava in Ohaji/Egbema in Imo State of southeastern Nigeria.

\section{Materials and Methods}

\subsection{Location}

The study area, Ohaji/Egbema in Imo State of Southeastern Nigeria is located on latitude $5^{\circ} 15^{\prime} 0^{\prime \prime} \mathrm{N}$ and $5^{\circ} 36^{\prime} 0^{\prime \prime} \mathrm{N}$ and longitude $6^{\circ} 35^{\prime} 0^{\prime \prime} \mathrm{E}$ and $7^{\circ} 0^{\prime} 0^{\prime \prime} \mathrm{E}$. It is an oil-rich Local Government Area of Imo State with Its headquarters at Mmahu-Egbema. The local council has an area of $890 \mathrm{~km}^{2}$ and lies in the southwestern part of Imo State. Besides Oil and Gas exploration, Ohaji/Egbema is in the rich agricultural zone of Imo State. Hence, agriculture is the mainstay of the people with faming, fishing, palm oil processing, hunting, and animal husbandry vigorously practiced. The area is naturally humid as the entire southeastern Nigeria, invariably, soils from the area humid which is good for crop production.

Moreover, Ohaji/Egbema is typically rainforest vegetation (Figure 1). Arable crops grow very well in the area which includes cassava, yam, maize, cocoa yam, etc. Therefore, soil moisture (helping chemical and biological activities of the soil) was expected to be high, while soil temperature (affecting physical and chemical processes in the soil) was expected to be low in the area. Therefore, for the purpose of this study, it was important to test characteristics of the soils from the area to know their potentials for production of the arable crops. 


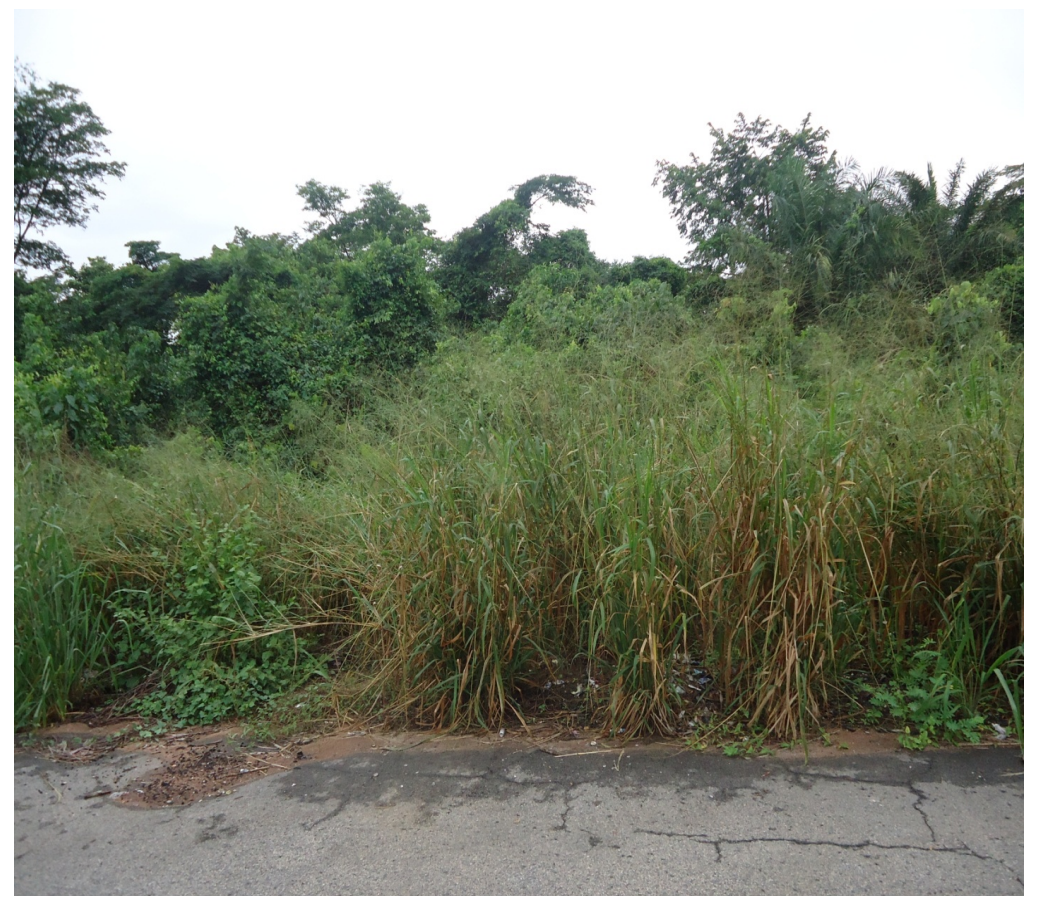

Figure 1. Rainforest vegetation at Mmahu, in Ohaji/Egbema in Imo State. Source: Field work, 2019.

\subsection{Primary Data Collection}

A free survey was employed for the study after the ten locations in the area was purposely selected for representation of the soil sampling. The free survey was guided by size and extent of farming activities in the area. Two types of sampling were conducted. Auger sampling was conducted at $0-20$ and $20-40 \mathrm{~cm}$ depths for arable crop production purposes while soil profile sampling was done for in-depth characterization and scientific classification of soils. Soil profile was dug, described and sampled using standard procedures as recommended by [19]. Soil samples were collected based on horizon differentiation (see Figure 2 and Figure 3). Sampling started from the deepest horizon upwards in each soil profile. Soil profiles were geo-referenced using hand held Global Positioning System (GPS) Receiver. Core soil samples were collected for bulk density determinations. Soil samples were bagged and taken to the laboratory for analysis.

\subsection{Secondary Data Collection}

The secondary data used was annual crop yield data on maize and cassava (in tons/hectare), for Imo State from 1988 to 2017 (30 years). The data was collected from Agriculture Development Programme (ADP) office in Owerri, Imo State. The crop yields data (see Table 1), for the entire state was used to represent crop yields for the study area, which was correlated with physicochemical soil properties to determine their relationship. The values of Maize and cassava in metric tons/hectare were obtained from the archrivals of the Agriculture Development Program (ADP), Owerri office, Imo State. 


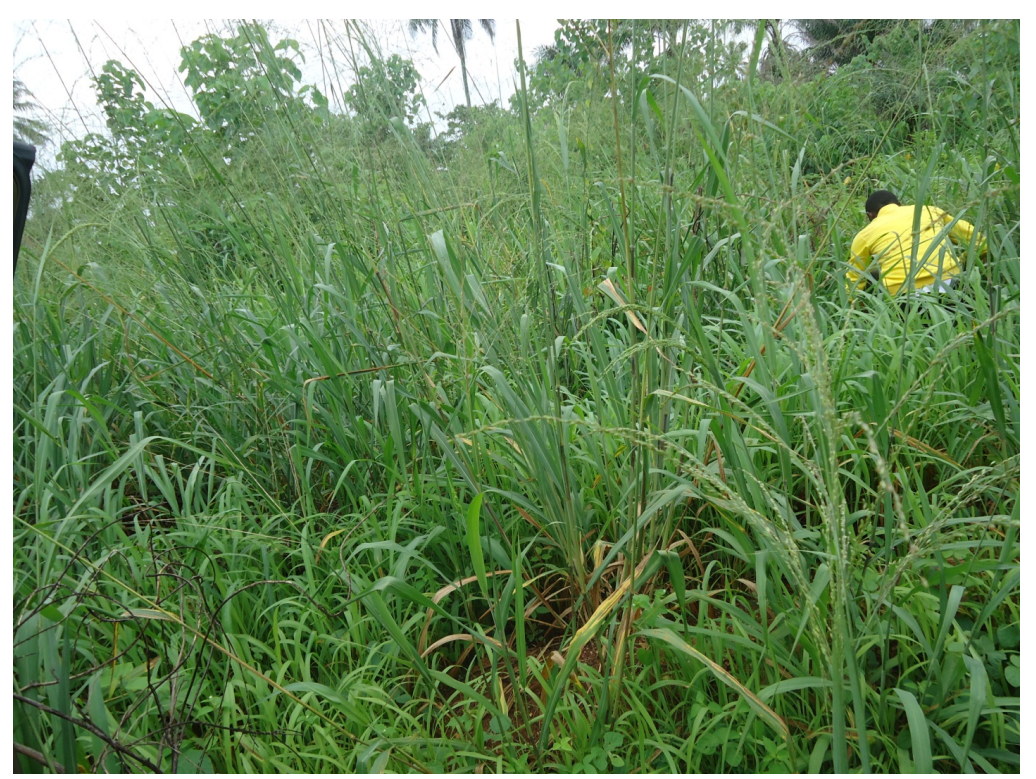

Figure 2. Soil samples collection at Obokafia Ohaji/Egbema, Imo State.

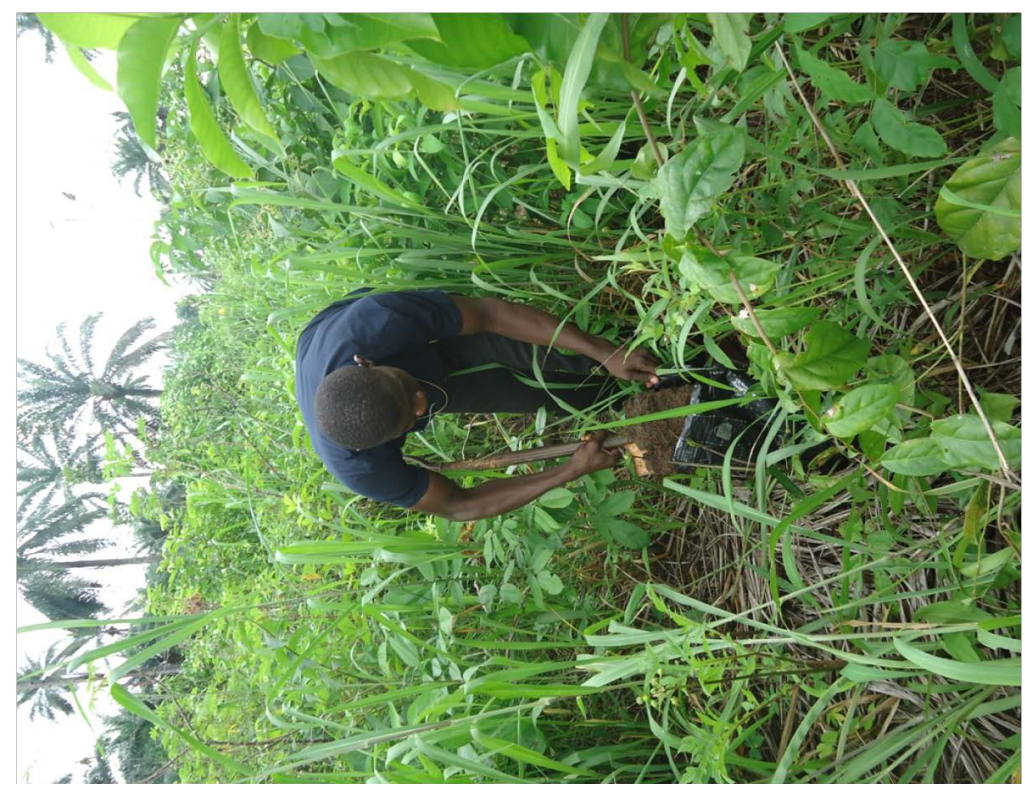

Figure 3. Field officer collecting soil samples at Mmahu, Ohaji/Egbema, Imo State.

\section{Results and Discussions}

\subsection{Results}

The primary and secondary data collected for this research were subjected to series of analytical methods including laboratory soil analyses, geospatial data analysis, and statistics models analysis.

\subsubsection{Laboratory Studies}

Soil samples were air-dried and sieved using 2-mm sieve.

Particle size distribution was determined by hydrometer method [20] while 
Table 1. Crop yield for Imo State in Metric tons (1988-2017).

\begin{tabular}{|c|c|c|}
\hline Year & Maize & Cassava \\
\hline 1988 & 1.92 & 6.40 \\
\hline 1989 & 1.50 & 7.80 \\
\hline 1990 & 1.95 & 6.55 \\
\hline 1991 & 1.90 & 6.75 \\
\hline 1992 & 1.85 & 6.80 \\
\hline 1993 & 1.92 & 6.40 \\
\hline 1994 & 1.50 & 7.80 \\
\hline 1995 & 1.55 & 7.55 \\
\hline 1996 & 3.00 & 8.20 \\
\hline 1997 & 3.06 & 7.88 \\
\hline 1998 & 3.20 & 7.90 \\
\hline 1999 & 2.17 & 13.58 \\
\hline 2000 & 2.14 & 13.24 \\
\hline 2001 & 2.15 & 12.99 \\
\hline 2002 & 2.21 & 13.90 \\
\hline 2003 & 2.07 & 13.76 \\
\hline 2004 & 2.21 & 14.02 \\
\hline 2005 & 2.40 & 16.21 \\
\hline 2006 & 2.32 & 14.87 \\
\hline 2007 & 2.16 & 14.99 \\
\hline 2008 & 1.31 & 14.94 \\
\hline 2009 & 1.35 & 14.91 \\
\hline 2010 & 1.35 & 15.08 \\
\hline 2011 & 1.43 & 15.07 \\
\hline 2012 & 1.80 & 14.47 \\
\hline 2013 & 2.39 & 15.60 \\
\hline 2014 & 2.40 & 15.65 \\
\hline 2015 & 2.50 & 15.85 \\
\hline 2016 & 3.05 & 15.90 \\
\hline 2017 & 3.05 & 15.75 \\
\hline Total & 63.81 & 360.81 \\
\hline
\end{tabular}

Source: ADP Owerri, Imo State.

bulk density was measure by core procedure [21]. Results from particle size analysis (sand, silt and clay) values were used to obtained textural class using textural triangle. In the process of the analysis, Robinson's pipette method (Pipette) and Bouyoucos hydrometer method were used.

Bulk density values were used to calculate total porosity of soils given a relationship between bulk density and particle density [22].

$$
\text { Total Porosity }(\mathrm{TP})=\frac{B D}{P D} \times 100
$$


where $B D=$ determined bulk density;

$P D=$ particle density assured to be $2.65 \mathrm{mg} \cdot \mathrm{m}^{-3}\left(2.65 \mathrm{~g} / \mathrm{cm}^{-3}\right)$.

Gravitaional moisture content $(\theta \mathrm{m})$ was measured using the procedure as outlined in [23].

$$
\theta m=\frac{N S-D S}{D S} \times 100 \%
$$

where $\theta m$ = gravimetric moisture content;

$W s=$ weight of wet soil sample;

$D s=$ weight of dry soil sample.

$$
A W C=F C-P W P
$$

Soil $\mathrm{pH}$ water and $\mathrm{pH}$ KCL were determined electronically in 1:2.5 soil solutions:water-ratio [24].

Soil organic Carbon was measured by wet digestion using the procedure outlined in [25].

Soil organic matter was calculated by multiplying organic carbon value by 1.724 .

Exchangeable basic cations were extracted using ammonium acetate at $\mathrm{pH}_{7}$. Therefore, exchangeable calcium and magnesium were determined using ethylene diamine-tetraascetic acid (EDTA) titration, and exchangeable potassium and sodium were determined by flame photometry [25].

Exchangeable acidity (exchangeable hydrogen and aluminum) were measured by apparent titration [26].

Cation exchange capacity (ACEC) was measured at $\mathrm{pH}$ of 7.0 (neutral) [25].

Total nitrogen (TN) was determined by micro-kjedahl apparatus [27]. Available phosphorous was estimated by Bray 2 method according to procedure of [28].

Base saturation was computed as a sum of exchangeable basic cations $(\mathrm{Ca}$, $\mathrm{Mg}, \mathrm{K}, \mathrm{Na}$ ) divided by Cation Exchange Capacity, multiplied by 100\% [25].

\subsubsection{Date Analytical Techniques}

In probability theory and statistics, coefficient of variation is a standardize measure of dispersion of a probability distribution or frequency distribution. It is a statistical measure of the distribution of data points in a data series around the mean, and it represents the ratio of the standard deviation to the mean. While variation is a measure of how far from the mean data set varies, coefficient of variation compares the standard deviation to the mean of each sample.

In this study, soil data from auger samples were subjected to analysis of variance (ANOVA). Therefore, variation in properties among soil horizons were obtained using coefficient of variation. Also, the correlation coefficient ( $r$ ) and the coefficient of determination for simple linear regression $\left(\mathrm{r}^{2}\right)$ were calculated to determine the degree of association or relationship among some physico-chemical properties of the soils from selected profiles around the study area. Similarly, soil parameters (independent variables) were correlated with crop yield (dependent 
variables) toestablish relationship between soil properties and production of maize and cassava in the area.

\subsubsection{Geospatial Data Analysis}

From the coordinates captured in the fields by the global positioning system device at the soil samples location points, Arc-GIS software was used in the GIS laboratory to produce GIS vector "soil sample collection location map" of the study area. Also digital elevation model DEM of the study area was produced using the coordinates (Figure 4 and Figure 5).

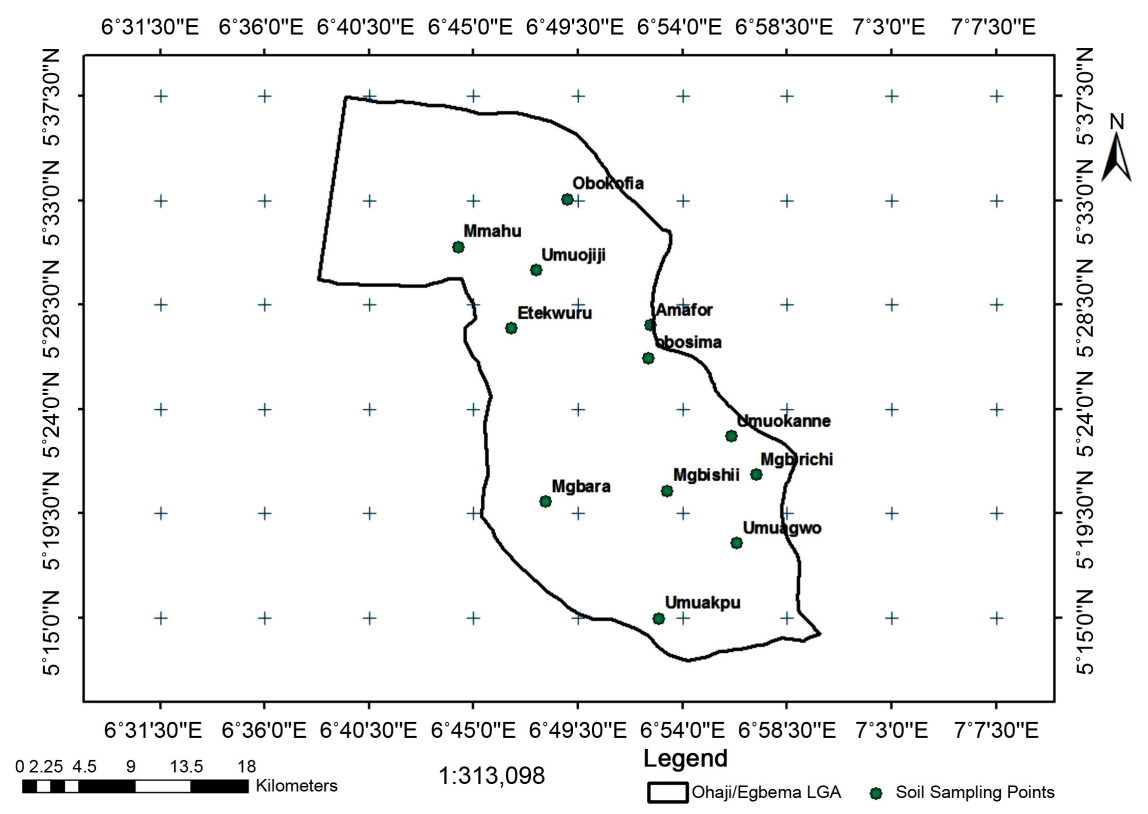

Figure 4. Area study map (Ohajie/Egbema) showing soil sampling locations.

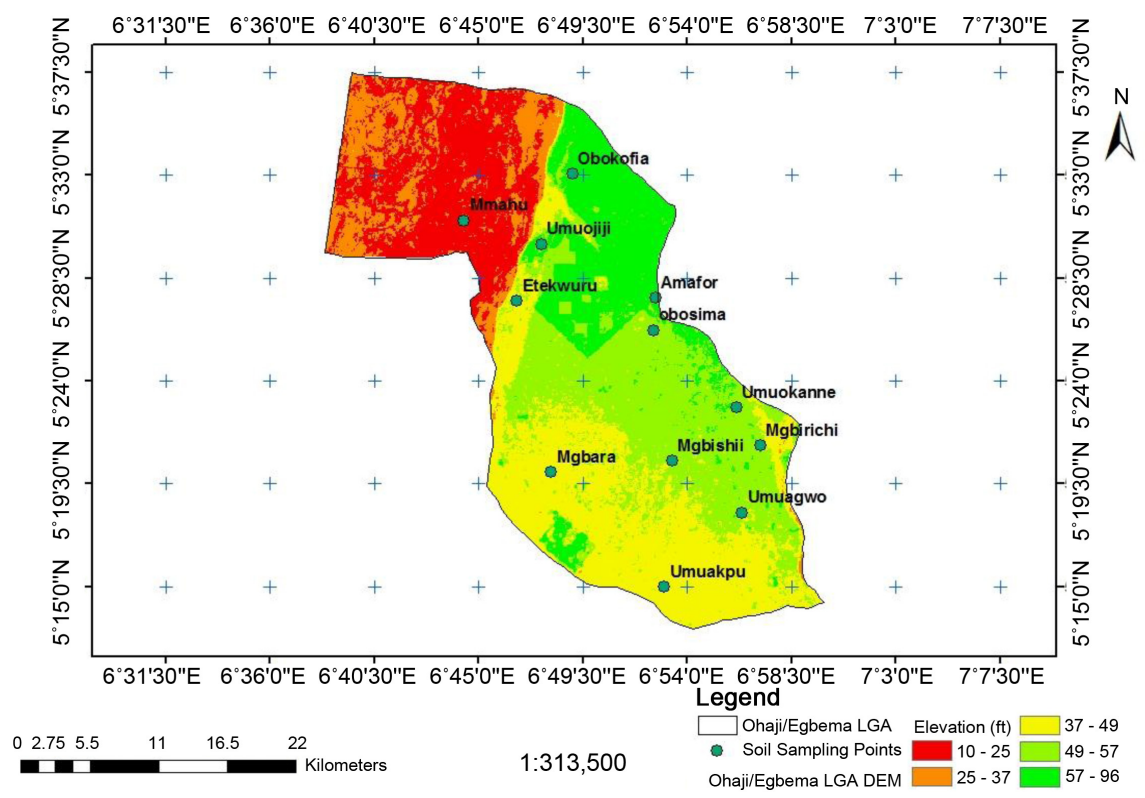

Figure 5. Study area map showing soil sampling points and elevations. 


\subsubsection{Physical Properties of Ohaji/Egbema Soils in Imo State}

The physical properties of soil of Ohaji/Egbema Local Government Area of Imo State are presented in Table 2. Statistical formula for standard error was used for the calculation regarding the soil physical properties (variables) shown in Table 2. The formula is given as; $S E=\sqrt{\left[\sum(x-\dot{x})^{2} / N\right]}$.

Results therefore, showed that the mean value of CS, FS, TS, Si and Cl from 0 $190 \mathrm{~cm}$ depth were 534, 132, 559.8, 26.4 and $307.6 \mathrm{~g} / \mathrm{kg}$ respectively. There were also variations in the textural classes of the soil from A to Bg3 horizons. The bulk density increased from A to Bg3 horizon due to higher organic matter content (Table 2). There were low variability in soil bulk density, coarse sand, total porosity and AWC and medium variability in clay, fraction, field capacity, and permanent wilting point. High variability occurred in fine sand, total sand, silt and moisture content.

\subsubsection{Chemical Properties of Ohaji/Egbema Soils in Imo State}

The chemical properties of soils in Ohaji/Egbema Local Government Area Imo State are shown in Table 3. The soils are strongly acidic with low variability. The mean values of organic carbon, organic matter, and total nitrogen were 11.74, 20.1 and $1.20 \mathrm{~g} \cdot \mathrm{kg}$ respectively. These values were low using [19] rating and the highest values were recorded at the epipedon ( $0-18 \mathrm{~cm}$ depth). This could be as a result of litter fall and higher biodiversity within this layer of soil.

Exchangeable $\mathrm{Ca}, \mathrm{Mg}, \mathrm{K}$ and $\mathrm{Na}$ were low. Effective cation exchange capacity and base saturation were low according to [29]. Available phosphorus was low with mean value of $14.68 \mathrm{mg} / \mathrm{kg}$. There was low variability in soil $\mathrm{pH}$. Exchangeable $\mathrm{K}$, and $\mathrm{Na}$, and base saturation while medium variation occurred in exchangeable $\mathrm{Mg}$, total exchangeable bases, effective cation exchange capacity, ACEC, and available P. Organic carbon, organic matter, total nitrogen, exchangeable $\mathrm{Ca}$ and $\mathrm{H}$ had high variability.

Table 2. Physical properties of Ohaji/Egbema soils in Imo State.

\begin{tabular}{|c|c|c|c|c|c|c|c|c|c|c|c|c|c|}
\hline 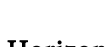 & Depth & CS & FS & TS & $\mathrm{Si}$ & $\mathrm{Cl}$ & $\mathrm{TC}$ & $\mathrm{BD}$ & TP & $\emptyset_{\mathrm{m}}$ & FC & PWP & AWC \\
\hline OII & $(\mathrm{cm})$ & $\mathrm{g} / \mathrm{kg}$ & $\mathrm{g} / \mathrm{kg}$ & $\mathrm{g} / \mathrm{kg}$ & $\mathrm{g} / \mathrm{kg}$ & $\mathrm{g} / \mathrm{kg}$ & & $\mathrm{g} / \mathrm{cm}^{3}$ & $\%$ & $\%$ & $\mathrm{~g} / \mathrm{kg}$ & $\mathrm{g} / \mathrm{kg}$ & $\mathrm{g} / \mathrm{kg}$ \\
\hline A & $0-18$ & 500 & 200 & 700 & 22 & 278 & SCL & 1.31 & 50.56 & 10.3 & 0.218 & 0.11 & 0.108 \\
\hline $\mathrm{AB}$ & $18-40$ & 510 & 210 & 720 & 10 & 270 & SCL & 1.37 & 48.3 & 9.6 & 0.212 & 0.113 & 0.099 \\
\hline Bg1 & $40-79$ & 490 & 100 & 59 & 30 & 380 & SC & 1.43 & 46.03 & 32.3 & 0.241 & 0.149 & 0.092 \\
\hline $\mathrm{Bg} 2$ & $\begin{array}{l}79- \\
130\end{array}$ & 520 & 100 & 620 & 20 & 360 & SC & 1.48 & 44.15 & 28.8 & 0.258 & 0.138 & 0.12 \\
\hline $\mathrm{Bg} 3$ & $\begin{array}{c}130- \\
190\end{array}$ & 650 & 50 & 700 & 50 & 250 & SCL & 1.55 & 41.5 & 30.4 & 0.331 & 0.229 & 0.102 \\
\hline Mean & & 534 & 132 & 559.8 & 26.4 & 307.6 & & 1.428 & 46.108 & 22.28 & 0.252 & 0.148 & 0.104 \\
\hline CV (\%) & & 12.3 & 52.9 & 50.5 & 56.8 & 19 & & 6.5 & 7.6 & 50.8 & 19 & 32.7 & 10.1 \\
\hline SE & & 65.3 & 69.8 & 285.6 & 14.99 & 58.3 & & 0.09 & 3.52 & 11.33 & 0.05 & 0.05 & 0.01 \\
\hline
\end{tabular}


Table 3. Chemical properties of Ohaji/Egbema soils in Imo State.

\begin{tabular}{|c|c|c|c|c|c|c|c|c|c|c|c|c|c|c|c|c|c|c|}
\hline Horizon & Depth $(\mathrm{cm})$ & $\begin{array}{c}\mathrm{pH} \\
(\mathrm{KCl})\end{array}$ & $\begin{array}{c}\mathrm{pH} \\
\left(\mathrm{H}_{2} \mathrm{O}\right)\end{array}$ & OC & $\mathrm{OM}$ & $\mathrm{TN}$ & $\mathrm{Ca}$ & $\mathrm{Mg}$ & K & $\mathrm{Na}$ & TEB & $\mathrm{H}$ & $\mathrm{Al}$ & TEA & ECEC & ACEC & Bsat & Av.P \\
\hline & & & & $\mathrm{g} / \mathrm{kg}$ & $\mathrm{g} / \mathrm{kg}$ & $\mathrm{g} / \mathrm{kg}$ & 4 & & & & $\begin{array}{c}\mathrm{Cmol} / \\
\mathrm{kg}\end{array}$ & & & & & & $\%$ & $\mathrm{Mg} / \mathrm{kg}$ \\
\hline A & $0-18$ & 4.3 & 5.2 & 24.9 & 43 & 2 & 1.6 & 0.5 & 0.12 & 0.8 & 2.32 & 0.4 & 1 & 1.4 & 3.72 & 7.82 & 62.36 & 15.6 \\
\hline $\mathrm{AB}$ & $18-40$ & 4 & 4.8 & 12.2 & 21 & 1.6 & 0.8 & 0.3 & 0.1 & 0.6 & 1.8 & 0.8 & 1.3 & 2.1 & 3.9 & 7.96 & 46.15 & 16.4 \\
\hline $\mathrm{Bg} 1$ & $40-79$ & 4.5 & 5.4 & 10.6 & 18.3 & 1.2 & 1 & 0.3 & 0.11 & 0.7 & 2.11 & 0.4 & 1 & 1.4 & 3.51 & 6.88 & 60.11 & 14.8 \\
\hline $\mathrm{Bg} 2$ & $79-130$ & 4.3 & 5.3 & 8.0 & 13 & 0.9 & 0.9 & 0.3 & 0.1 & 0.6 & 1.9 & 0.3 & 0.9 & 1.2 & 3.1 & 6.45 & 61.29 & 16.2 \\
\hline $\mathrm{Bg} 3$ & $130-190$ & 4.1 & 4.9 & 3.0 & 5.2 & 0.3 & 0.6 & 0.2 & 0.09 & 0.6 & 1.49 & 0.2 & 0.9 & 1.1 & 2.59 & 5.32 & 57.52 & 10.4 \\
\hline Mean & & 4.24 & 5.12 & 11.74 & 20.1 & 1.2 & 0.98 & 0.32 & 0.104 & 0.66 & 1.924 & 0.42 & 1.02 & 1.44 & 3.364 & 6.886 & 57.486 & 14.68 \\
\hline CV (\%) & & 4.6 & 5.1 & 69.3 & 70.4 & 54.3 & 38.5 & 34.2 & 11 & 13.6 & 16.3 & 54.3 & 16.1 & 27.2 & 15.6 & 15.7 & 11.5 & 16.8 \\
\hline SE & & 0.19 & 0.25 & 8.14 & 14.2 & 0.65 & 0.38 & 0.11 & 0.01 & 0.09 & 0.32 & 0.23 & 0.16 & 0.39 & 0.23 & 1.08 & 6.59 & 2.47 \\
\hline
\end{tabular}

\subsubsection{Relationship between Soil Properties and Crop Yield in the Study Area}

Results of the relationship between soil properties and crop yield are presented in Table 4. Results showed that there was significant positive relationship between moisture content and cassava yield $(r=0.6743)$ and significant negative correlation between moisture content and maize yield $(r=-0.6490)$. Exchangeable $\mathrm{Al}$ significantly correlated positively with cassava yield and negatively with maize yield. Bulk density, CS, exchangeable $\mathrm{K}$ and TS significantly correlated negatively with cassava yield and positively with maize yield. There was significant positive relationship between $\mathrm{Cl}$, effective cation exchange capacity, exchangeable $\mathrm{Mg}$, Si, total porosity and total $\mathrm{N}$ with cassava yield and negative relationship with maize yields. The results showed that soil properties influence the yield of cassava and maize in the area and Imo State in general. Therefore improving the fertility status of soil and improving soil quality is a panacea for better cassava and maize yield. Similarly some soil properties that favour cassava yield may not favour maize yield and hence understanding these factors will help in policy managing agricultural lands for crop production.

The " $r$ " means the correlation coefficient value for the relationships between soil properties and crop yields. Hence, soil data from auger sample were statistically correlated with crop yields using coefficient of variation at both the 0.01 and 0.05 probability levels.

\subsection{Discussion}

Generally, this research supports previous studies, which revealed that physical and chemical properties of soils influence crop yields in different regions of the world. Soil physical properties determine how easily plant roots can grow to access soil nutrients, and how easily water can flow through the soil to deliver these nutrients. Supporting this, studies in Southern Cameroon by [30] [31]; in Nigeria by [32] and [33]; in the US by [34]; show that soil physical properties affected maize grain yields [35], indicated that inadequate moistures in the soil 
Table 4. Relationship between soil factors and yields of maize and cassava in the study area.

\begin{tabular}{|c|c|c|}
\hline Parameter & Cassava yield & Maize yield \\
\hline Cassava Yield & 1 & \\
\hline Maize Yield & $-0.9728^{* *}$ & 1 \\
\hline Moisture Content & $0.6743^{*}$ & $-0.649^{*}$ \\
\hline Anion Exchange Capacity & 0.4834 & -0.4627 \\
\hline Available Water Capacity (AWC) & 0.4557 & -0.4740 \\
\hline Exchangeable Al & $0.7573^{* *}$ & $-0.6948^{*}$ \\
\hline Available Phosphorus & 0.2843 & -0.1926 \\
\hline Bulk Density & $-0.627^{*}$ & $0.6506^{*}$ \\
\hline Base Saturation & 0.2254 & -0.2826 \\
\hline CS & $-0.8557^{\star *}$ & $0.8742^{* *}$ \\
\hline Exchangeable $\mathrm{Ca}$ & 0.0119 & -0.0827 \\
\hline $\mathrm{Cl}$ & $0.7162^{\star *}$ & $-0.7728^{\star *}$ \\
\hline ECEC & $0.5713^{*}$ & $-0.5496^{*}$ \\
\hline FC & 0.4768 & -0.4589 \\
\hline FS & 0.1089 & -0.0938 \\
\hline Exchangeable $\mathrm{H}$ & 0.4221 & -0.2155 \\
\hline Exchangeable K & $-0.596^{*}$ & $0.5759^{*}$ \\
\hline Exchangeable $\mathrm{Mg}$ & $0.6911^{*}$ & $-0.6845^{\star}$ \\
\hline Exchangeable $\mathrm{Na}$ & -0.3452 & 0.3437 \\
\hline Organic Carbon & 0.4232 & -0.4928 \\
\hline Organic Matter & 0.4232 & -0.4927 \\
\hline PWP & 0.4655 & -0.3865 \\
\hline $\mathrm{Si}$ & $0.7750^{*}$ & $-0.7222^{\star *}$ \\
\hline Total Exchangeable Acidity & $0.7215^{\star}$ & $-0.6149^{*}$ \\
\hline Total Exchangeable Bases & 0.4036 & -0.4344 \\
\hline Total N & $0.5333^{*}$ & $-0.5928^{\star}$ \\
\hline Total Porosity & $0.6258^{*}$ & $-0.6495^{*}$ \\
\hline TS & $-0.7501^{\star \star}$ & $0.7774^{\star \star}$ \\
\hline $\mathrm{pH}\left(\mathrm{H}_{2} \mathrm{O}\right)$ & 0.0441 & -0.041 \\
\hline
\end{tabular}

${ }^{*}$ and ${ }^{* *}=$ sig at 0.05 and 0.01 probability levels respectively. Source: Field work (2019).

reduce maize production.

[36] reported, very low to moderate silt/clay ratios (0.04 to 0.029$)$ that generally decreased with depth while working on soils at Isienyi Ibeku, which is within Ikwuano soil zone in Abia State. This study however reported high to very high silt/clay ratios (1:2.99) in Ohaji/Egbema in general, and the ratios increased with depth, which was in agreement with the research by [37], which reported that the bulk density of sub surface horizons were usually significantly greater than those of surface horizons. The value of bulk density in the study area at $0-20 \mathrm{~cm}$ 
depth was $1.33 \mathrm{~g} / \mathrm{cm}^{3}$ while the value at $20-40 \mathrm{~cm}$ depth was $1.39 \mathrm{~g} / \mathrm{cm}^{3}$.

This supports that $\mathrm{BD}$ increases with increase in depth down the profile. This research further observed that there is irregular silt to sand ratio in the entire Southeast Nigeria.

[38] reported high variations in silt fraction and total sand and fine sand in southeast Nigeria. This study showed high and irregular variations these soil properties which supports the previous study by [38].

This research showed that $\mathrm{pH}$ in water $\left\{\mathrm{pH}\left(\mathrm{H}_{2} \mathrm{O}\right)\right\}$ was higher than $\mathrm{pH}$ in $\mathrm{KCl}$ $\{\mathrm{pH}(\mathrm{KCl})\}$. For example, mean of $\mathrm{pH}$ in water was 5.12 and $\mathrm{pH}(\mathrm{KCl}), 4.24$, and generally, the soil of the area was highly acidic with low $\mathrm{pH}$ values. Hence [14], reported that such reaction is characteristic of soils in southeastern Nigeria and it is the result of the acidic nature of the parent rocks, coupled with the influence of the leached profile under high annual rainfall condition.

[39] and [40] reported that total nitrogen is usually highest in the topsoil, decreasing down the profile. In support, this research reported high values of total nitrogen at the topsoil in Ohaji/Egbema, decreasing down the profile, from 2 $\mathrm{g} / \mathrm{kg}$ at A horizon to $0.3 \mathrm{~g} / \mathrm{kg}$ at $\mathrm{Bg} 3$. These results generally showed that the nitrogen values are decreasing down the profile.

[13] reported, that organic matter was generally highest in the top most horizon of Imo River Basin and highest in the topsoil because of the continuous addition of organic matter to the soil surface by plant residues. This study, however, is in consonance with the reports of the previous studies by indicating that organic matter contents in the study area are generally higher in the topsoil. In the area, OM decreased from total value of $124.46 \mathrm{~kg}$ in the topsoil to $67.56 \mathrm{~kg}$ in the sub soil.

ECEC was reported to be low in Imo river basin [16] [17] [18]. The present study supports previous studies by reporting also a low ECEC in the area with total value of $11.63 \mathrm{cmol} / \mathrm{kg}$ in the top soil and $10.63 \mathrm{cmol} / \mathrm{kg}$ in the subsoil. However, the values of ECEC decrease with increase in depth, which is a common condition with most soil properties in the southeast Nigeria as reported in other studies.

\section{Conclusions}

The study established that there are variations in physical and chemical properties of soils in Ohaji/Egbema area of Imo State, Nigeria and the variability in the soil properties which affect crops growing in the area. It further indicated that the soil properties negatively influenced maize and cassava yields, particularly in the area, and it is susceptible to future decrease. From the study also, it is observed that Ohaji/Egbema soil contains less plant nutrient elements that will support crop production. Therefore, the chemical properties of soils in the area are low according to [19] and [29] soil fertility rating. Hence, there is therefore need to boost the productivity of soils in the area and entire Imo State for maximum crop production, in order to achieve sustainable food security. 
However, apart from soil characteristics, there are other factors that can cause variations in cassava and maize yield in the area. These factors are, not limited to;

- Farm machines or technologies in use;

- Climate change and variability;

- Level of fertilizer and insecticide application;

- Adaptive practices to rainfall variation and climate change;

- Educational level and farming experience of the farming population.

\section{Recommendations}

The data for this research allow suggesting recommendations to achieve increased productivity and resources use efficiency for these major food crops in the area.

Therefore, the government will need to design policies to counteract the effects of climate change in relation to agriculture. This will allow farmers to adjust their management strategies like early planting and to minimize the risk of crop failure.

Also, since this study ascertained that some soil properties negatively influence production of maize and cassava in the area, therefore, improving the fertility status of soil and improving soil quality will be a panacea for better maize and cassava yield. Similarly, some soil properties that favour maize yield may not favour cassava yield and thus, understanding these factors will help in policy managing agricultural lands for crop production. Therefore, farmers in this region can reduce the potential damage through adaptation such as the practice of organic agriculture, which is one of the most important strategies for adaptation to climate change and variability.

Furthermore, using different crop varieties with varying planting dates is significant at farm level. Since different crops are affected differently by climatic changes, farmers in the area can grow varieties of crops on the same farmland or on a different lands and this will reduce the risk of complete crop failure.

They are as well recommended to practice crop adaptation using possible existing genetic diversity and biotechnology.

Finally, farmers in the region should resort to some more management practices such as contour ploughing, ridges and cross-bars between ridges, which will definitely reduce erosion and runoff thereby preventing leaching of soil nutrients.

\section{Acknowledgements}

Nigerian Tertiary Education Trust Fund (TETFUND) is solely acknowledged for sponsoring this research through Institutional Base Research (IBR) programme. Also, Imo State University Owerri (our Institution), is highly acknowledged for attracting the research funding. Franklyn Okoro and two other persons are acknowledged for taking the research team round the study area during field studies. 


\section{Conflicts of Interest}

The authors declare no conflicts of interest regarding the publication of this paper.

\section{References}

[1] Gobin, A., Jones, R., Kirby, M., Campling, P., Govers, G., Kosmas, C. and Gentile, A.R. (2004) Indicators for Pan-European Assessment and Monitoring of Soil Erosion by Water. Environmental Science \& Policy, 7, 25-38. https://doi.org/10.1016/j.envsci.2003.09.004

[2] Nsoanya, L.N. and Nenna, M.G. (2011) Adoption of Improved Cassava Production Technologies in Anambra-East Local Government Area of Anambra State Nigeria. Journal of Research in National Development, 9.

http://www.transcampus.org http://www.ajol.info/journals/jorind

[3] Ani, A.O. (2002) Factors Inhibiting Agricultural Projection among Rural Women Farmers in Southern Ebonyi State, Nigeria. Ph.D. Thesis, University of Maiduguri, Maiduguri.

[4] Tsegai, D. and Kormawa, P.C. (2002) Determinants of Urban Household Demand for Cassava Products in Kaduna, Northern Nigeria. Conference of International Research for Development, Witzenhause, 9-10 October 2002.

[5] Ezedinma, C., Dixon, A., Sanni, G.O., Okechukwu, L., Akoroda, R., Lemehi, M., Ogbe, J. and Okoro, E. (2006) Trends in Cassava Production and Commercialization in Nigeria. International Institute of Tropical Agriculture.

[6] Onweremadu, E.U. (2012) Optimum Soil Nutrients: A Sine Qua Non for Sustainable Agriculture for Food and Nutrition Security. In: Miransari, M., Ed., Soil Nutrients, Nova Science Publishers Inc., New York, 215-265.

[7] Battiano, A. and Mokwunye, A.U. (1991) Role of Manure and Crops Residue in Alleviating Soil Fertility Constraints to Crop Production, Fertility Research. Journal of Crop Science.

[8] Agboola, T. and Ojeleye, D. (2007) Climate Change and Food Crop Production in Ibadan, Nigeria. African Crop Science Conference Proceedings, 8, 1423-1433.

[9] Ogbodo, E.N. (2013) The Fertility and Management Imperatives of the Degraded Upland Soils of Ebonyi State, Southeast, Nigeria. Nigerian Journal of Soil Science, 23, 168-177.

[10] Lia, R. (1979) Physical Characteristic of Soil in the Tropics. In: Lar, R. and Greenland, D., Eds., Determination and Management, Willey and Sons, Hoboken.

[11] Salako, F.K. (2003) Soil Physical Conditions in Nigeria Savannas and Biomass Production. The College on Soil Physics, Trieste, 3-21 March 2003.

[12] Esu, I.E. (2005) Characterization, Classification and Management Problems of Major Soil Orders in Nigeria. The 26th Inaugural Lecture of the University of Calabar, Calabar, $66 \mathrm{p}$.

[13] Enplan Group (1981) Oramiriukwa River Project Report. Anambra-Imo River Basin Development Authority, Owerri.

[14] Eshett, E.T., Omoeti, J.A.I. and Juo, A.S.R. (1990) Physico-Chemical Morphological and Clay Mineralogical Properties of Soils Overlying Basement Complex Rocks in Ogoja, Northern Cross River State of Nigeria. Soil Science and Plant Nutrition, 36, 203-214. https://doi.org/10.1080/00380768.1990.10414985 
[15] Landon, J.R. (1991) Booker Tropical Soil Manual: A Handbook for Soil Survey and Agricultural Land Evaluation in the Tropics and Sub-Tropics. Addison Wesley Longman Limited, Essex, 472 p.

[16] Njoku, B.O. and Ogbuehi, S.N. (1982) Soil Fertility Aspects of Mealy Bug and Green Spider Control. Proceedings of the International Workshop on Control of Cassava Meal Bugs and Green Spider Mites of March, 7-11.

[17] Duguma, B., Kang, B.Y. and Okali, D.U.U. (1988) Effects of Liming and Phosphorus Application on Performance of Leucaena leucocephala in Acid Soils. Plant and Soil, 110, 57-61. https://doi.org/10.1007/BF02143539

[18] Osuji, G.E., Eshett, E.T., Oti, N.N. and Ibeawuchi, I.I. (2002) Land Use Practice and the Predisposition of Selected Watersheds in Imo State to Erosion. Proceedings of the 36th Annual Conference of the Agricultural Society of Nigeria, Owerr, 397-401.

[19] FAO (Food and Agricultural Organization) (2006) Guidelines for Soil Description. 4th Edition, Food and Agriculture Organization of the United Nations, Rome, $97 \mathrm{p}$.

[20] Gee, G.W. and Or, D. (2002) Particle Size Analysis. In: Dane, J.H. and Topp, D.C., Eds., Methods of Soil Analysis, Part 4. Physical Methods, Soil Science Society of America Book Series No. 5, ASA and SSSA, Madison, 255-293.

https://doi.org/10.2136/sssabookser5.4.c12

[21] Grossman, R.P. and Reinschi, T.G. (2002) Bulk Density and Linear Extensibility. In: Dane, J.H. and Topp, D.C., Eds., Methods of Soil Analysis, Part 4. Physical Methods, Soil Science Society of America Book Series No. 5, ASA and SSSA, Madison, 201-228. https://doi.org/10.2136/sssabookser5.4.c9

[22] Foth, H.D. (1984) Fundamentals of Soil Science. 7th Edition, John Wiley and Sons, New York, 435 p.

[23] Obi, M.E. (1990) A Compendium of Lectures. Department of Soil Science, University of Nigeria, Nsukka, $102 \mathrm{p}$.

[24] Hendershot, W.H., Laland, H. and Duquette, M. (1993) Soil Reaction and Exchangeable Acidity. In: Carter, M.R., Ed., Soil Sampling and Methods of Soil Analysis, Lewis Publishers, London, 141-145.

[25] Soil Survey Staff (2010) Keys to Soil Taxonomy. 11th Edition, USDA-NRCS, Washington DC, $338 \mathrm{p}$.

[26] Soil Survey Staff (2003) Keys to Soil Taxonomy. 9th Edition, Natural Resources Conservation Service, United States Department of Agriculture (USDA), Washington DC, $332 \mathrm{p}$.

[27] Bremner, J.M. (1996) Nitrogen Total. In: Sparus, D.L., Ed., Methods of Soil Analysis Part 3, Chemical Methods, Vol. 5, Soil Science Society of America Book Series, Wiley-Interscience, New York, 1085-1122. https://doi.org/10.2136/sssabookser5.3.c37

[28] Olson, R.S. and Sommers, L.E. (1982) Phosphorous. In: Page, A.L., Miller, R.H. and Keeney, D.R., Eds., Methods of Soil Analysis, Am. Soc. Agron., Madison, 403-430.

[29] Esu, I.E. (1991) Detailed Soil Survey of NIHORT Farm at Bunkure, Kano State, Nigeria. Institute for Agricultural Research, Ahmadu Bello University, Zaria.

[30] Tueche, J.R. (2014) Relationships between Soil Physical Properties and Crop Yields in Different Cropping Systems in Southern Camerron. Ph.D. Thesis of Faculty of Agricultural Sciences, University of Stuttgart, Stuttgart.

[31] Yemefack, M. and Nounamo, L. (2000) Dynamique des Sols et Durée Optimale des Jachères Agricoles Naturelles au Sud Cameroun. In: Floret, C.H. and Pontanier, R., Eds., La Jachère en Afrique Tropicale: Rôles, Aménagement, Alternatives, John Libbey Eurotext, Paris, 135-141. 
[32] Lal, R. (1997) Long-Term Tillage and Maize Monoculture Effects on a Tropical Alfisol in Western Nigeria. I. Crop Yield and Soil Physical Properties. Soil and Tillage Research, 42, 145-160. https://doi.org/10.1016/S0167-1987(97)00006-8

[33] Lal, R., Follent, F., Stewart, B.A. and Kimble, J.M. (2002) Soil Carbon Sequestration to Mitigate Climate Change and Advance Food Security. Soil Science, 172, 943-956. https://doi.org/10.1097/ss.0b013e31815cc498

[34] Jagadamma, S., Lal, R., Hoeft, R.G., Nafziger, E.D. and Adee, E.A. (2008) Nitrogen Fertilization and Cropping System Impacts on Soil Properties and Their Relationship to Crop Yield in the Central Corn Belt, USA. Soil and Tillage Research, 98, 120-129. https://doi.org/10.1016/j.still.2007.10.008

[35] Magehema, A.O., Chang, L.B. and Mkoma, S.L. (2014) Implication of Rainfall Variability on Maize Production in Morogoro, Tanzania. International Journal of Environmental Sciences, 4, 1077-1086. https://doi.org/10.6088/ijes

[36] Onweremadu, E.U. and Anikwe, M.A.N. (2007) Soil Wettability Characteristics of a Forested Catena in Relation to Organic Matter Fractions. International Journal of Soil Science, 2, 211-217. https://doi.org/10.3923/ijss.2007.211.217

[37] Iqbal, J., Thomasson, J.A., Jenkins, J.N., Owens, P.R. and Whisler, F.D. (2005) Spatial Variability Analysis of Soil Physical Properties of Alluvial Soils. Soil Science Society of America Journal, 69, 1338-1350. https://doi.org/10.2136/sssaj2004.0154

[38] Asadu, C.L.A. (1986) Pedological Studies of Six Soil Toposequences on Thee Sedimentary Formations in Anambra State, Nigeria. M.Sc. Thesis, University of Nigeria Research Publications, Nsukka, 215 p.

[39] Ohiri, A.C., Igbokwe, M.C. and Lekwa, G. (1985) Physico-Chemical Characteristics, Classification and Management of Selected Yam Soils of Northern Nigeria. Proceedings of the International Society of Soil Science, 68-81.

[40] Ukaegbu, E.P. and Akamigbo, F.O.R. (2004) Influence of Physiography on the Properties and Land Use of Soils of the Cross River Plains: A Case Study of a Strip of Land at Ishiagu, Ebonyi State. Proceedings of the 29th Annual Conference of the Soil Science Society of Nigeria, Abeokuta, 103-109. 